\title{
The Role Of The Merangin Regency Government Through Welfare Policy In The Globalization Era
}

\author{
Pahrudin HM$^{1 *}$ \\ ${ }^{1}$ Department of Political Science, Faculty of Social Science and Politic, \\ Universitas Jambi \\ Jalan Raya Jambi-Muara Bulian KM 15, Mendalo Darat, Muaro Jambi, Jambi, Indonesia. \\ Email: pahrudinhm9@gmail.com

\begin{abstract}
The background of this research is related to two things, namely: how the forms of roles that can be carried out by the Merangin Regency Government in the era of globalization and how they affect the welfare of society public. The purpose of this study is to analyze the role of government to improve the welfare of society in the era of globalization. The discourse of globalization gave rise to radical groups who thought that the government did not need to intervene in development because it was carried out by the private sector and were skeptical that it was precisely because of the many negative effects of globalization that it became an important entry point for that role. This study uses a qualitative approach by analyzing public policy from the Merangin District Government and community welfare data. The study results show that local governments play an important role in exploiting opportunities and preventing the negative impacts of globalization. In conclusion through a series of innovative and solutive policies, the Merangin District Government seeks to improve the welfare of the community by utilizing its local potential.
\end{abstract}

Keyword: globalization, government role, public policy, welfare. 


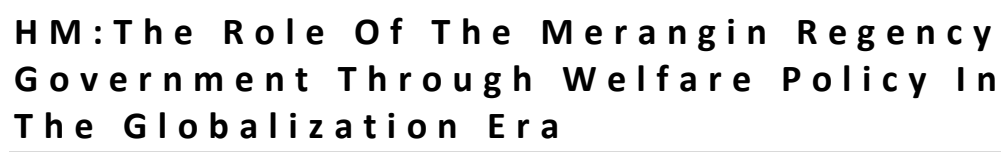

\begin{abstract}
Abstrak
Latar belakang penelitian ini terkait dengan dua hal, yaitu: bagaimana bentuk peran yang dapat dilakukan oleh Pemerintah Kabupaten Merangin di era globalisasi dan bagaimana pengaruhnya terhadap kesejahteraan masyarakat. Tujuan dari penelitian ini adalah untuk menganalisis peran pemerintah untuk meningkatkan kesejahteraan masyarakat di era globalisasi. Wacana globalisasi memunculkan kelompok-kelompok radikal yang berpikir bahwa pemerintah tidak perlu campur tangan dalam pembangunan karena dilakukan oleh sektor swasta dan skeptis karena banyak efek negatif globalisasi yang menjadi penting titik masuk untuk peran itu. Penelitian ini menggunakan pendekatan kualitatif dengan menganalisis kebijakan publik dari Pemerintah Kabupaten Merangin dan data kesejahteraan masyarakat. Hasil studi menunjukkan bahwa pemerintah daerah memainkan peran penting dalam mengeksploitasi peluang dan mencegah dampak negatif globalisasi. Sebagai kesimpulan melalui serangkaian kebijakan inovatif dan solutif, Pemerintah Kabupaten Merangin berupaya meningkatkan kesejahteraan masyarakat dengan memanfaatkan potensi lokalnya.
\end{abstract}

Kata kunci: globalisasi, peran pemerintah, kebijakan publik, kesejahteraan. 


\section{INTRODUCTION}

The study of the role of The Merangin Regency Government of Jambi Province through the implementation of various policies aimed at improving the welfare of the people in this globalization era is interesting and important to do. The significance of this study is due to several reasons as follows, namely:

First, based on BPS data (2018), Merangin Regency is the largest area in Jambi Province $(7,679 \mathrm{~km} 2 / 15.31 \%)$, one of the largest population in Jambi Province (377,905 people), has a total rubber plantation area of 131,413 Ha (the largest in the Province Jambi), and most of the population (79.31\%) works in the agriculture, plantation and forestry sectors. While on the other hand, welfare indicators are relatively not encouraging, such as the still-high poverty rate (9.43\%), and the Human Development Index (HDI) which is still below Jambi Province and other Regency (68.81). This fact certainly requires a good 'touch' from The Merangin Regency Government so that the great potential is exploited and the problem is resolved. Estuary, of course, there is an increase in the standard of living of the community in all its aspects.

Second, the massive application of globalization throughout the world has both positive and negative impacts on society, so the government needs to take a significant role in utilizing the 'good' side and overcoming the 'bad' aspects of it (Wolf 2016). Globalization has been massively applied all over the world since 1980 in line with the increasingly dominant Western Block which was commanded by the United States in the world arena after the collapse of the Soviet Union with its Eastern Bloc. As a system, globalization certainly raises its impact on the world community. On the one hand, globalization has a positive impact on efforts to obtain a decent standard of living (Friedman 2007). This is because globalization provides the same arena of competition for each country to take advantage of the opportunities provided. The phenomenon of the success of China and India that exploits the opportunities provided by globalization so that the economy has increased, and even then became two new powers of the world economy deserve an example. But on the contrary, globalization has also led to negative excesses throughout the world. According to Petras and Veltmeyer (2001), globalization is only enjoyed by Developed Countries, while Third World countries only act as spectators, and even become victims of the various negative excesses it causes. Globalization also marginalizes farmers in Third World 
countries because various global trade rules make them increasingly marginalized, even uprooted from the systems, professions and ways of life that they have been doing (Pahrudin 2016). Globalization is also claimed to erode the economic system and local culture that exist in Third World countries because projects financed by capital agencies (IMF) are mostly implemented in regions without prior discussion with residents (Pahrudin 2016).

Globalization which is claimed as a means to the welfare of the world community is no more than a myth, based on the following five arguments (Heri 2014)First, the openness of the international economy which is used as a telling form for advocates of globalization to attract the sympathy of the world is actually not more open than in 1870 to 1914 . Second, the existence of purely transnational companies as one of the agents of globalization is difficult to find because even though it is nationally based, its marketing reaches across countries and internationally to strengthen national assets, production, and sales. Third, capital mobility claimed by supporters globalization will flow profusely into the Third World, not fully becoming a reality because it is more concentrated in Developed Countries, while the Third World remains in a marginal position. Fourth, the goal of creating an economy as claimed by proponents of globalization is not achieved. as global trade, investment and financial flows concentrate more on the European Single Trio (Britain, France, and Germany), Japan and North America, including China and India. Finally, because it is not evenly distributed throughout the world, Britain, France, Germany, Japan, the United States, and Canada control every aspect of the world economy in line with its objectives.

Table1:

World Economic Relations in The Globalization

\begin{tabular}{|c|c|c|c|}
\hline No. & $\begin{array}{c}\text { Triad } \\
\text { Countries }\end{array}$ & Hinterlands & Economic Interest \\
\hline 1 & North America & $\begin{array}{l}\text { Latin America, Caribia } \\
\text { and the Middle East }\end{array}$ & $\begin{array}{l}\text { Control of world oil prices, } \\
\text { cheap labor and mineral mines }\end{array}$ \\
\hline 2 & Western Europe & Africa andEast Europe & $\begin{array}{l}\text { Consumer market, cheap } \\
\text { production factors, and industrial } \\
\text { raw material dick. }\end{array}$ \\
\hline 3 & East Asia & $\begin{array}{l}\text { Southeast Asia, Central } \\
\text { Asia, South Asia, and the } \\
\text { South Pacific. }\end{array}$ & $\begin{array}{l}\text { Consumer market, cheap } \\
\text { production factors, and industrial } \\
\text { raw material control }\end{array}$ \\
\hline
\end{tabular}


In line with the above, (Tandon 2009) proposes facts related to the global economy that are not global because only controlled and dominated by three world powers. The three major world powers named the Triad are North America, Western Europe and East Asia controlling the resources owned by the hegemon region (hinterland), as in Table 1 above.

According to Samir Amin(Jurdi 2015), globalization is a metamorphosis of the third occupation by the West of the Third World, having previously practiced mercantilism and imperialism. Along with the collapse of the Soviet Union, the pattern of imperialism in the format of globalization undertaken to strengthen the Central Trio (the United States, Western Europe and Japan) received support from several powers, namely the authority to intervene in the domestic affairs of other countries strengthened by democracy, the right people and humanity. This was further strengthened by the strategy of showing Western military power in various countries affiliated with it to ensure its hegemony remained strong. In the same context, (Yustiningrum 2015)also states that globalization is an attempt made by the West, especially Britain, to spread modernity and capitalism throughout the world.

Thus a series of positive and negative impacts and views from the implementation of globalization throughout the world is suspected by many groups. Related to some of the above impacts, the discourse of globalization has led to a debate among experts about the role of the state or government in development. The issue of the role played by the state or government is one of the central themes in the debate around globalization. This is because as the party assigned to state management, the government as a manifestation of the state should play an active role in overcoming the problems faced by its people. The intended role manifests itself in public policies interpreted by Steven A. Peterson (Riant 2018)as an action taken by the government to overcome various problems. Likewise, a public policy which is understood (Agutino 2016). as an action taken by the authorities, has a specific purpose or purpose, is not random or planned, has goals and is goal-oriented, and is based on applicable rules. Globalization with all its impacts needs to get the attention of the government so that the positive excesses can be put to good use and the negative excesses can be avoided by the people. 
Third, local governments play a significant role in efforts to improve people's welfare in the era of regional autonomy (Amien 2005). As it is known that after the reformation that was rolled out since 1998, Indonesia changed the paradigm of governance from centralized to decentralized. If previously, the affairs of the people were the responsibility of the central government in full, then the decentralized system made it the affairs of the regional government. The choice of a system which is also known as regional autonomy is certainly not merely to appear different from the steps taken by the replaced New Order government. Decentralization was chosen because it was based on rational considerations made by all leaders of this nation. Decentralization is believed to be an effective solution to overcome the various problems that emerged when Indonesia was in a period of centralization.

According to Bird and Vaillancourt (1998), a decentralized system was chosen as a government system because it has several advantages. First, decentralization policies that form the basis of post-reform regional management promise economic efficiency, program cost-effectiveness, accountability, increased resource mobilization, reduced disparity, increased political participation and strengthened democracy and political stability. Second, through decentralization, local governments are considered to have better knowledge about the needs and preferences of their citizens, so the development process in the decentralization policy model should be more efficient than the centralized policy model in the framework of improving the welfare of local communities (Bird, R., dan Vaillancourt 1998).

These are some of the advantages possessed by decentralization that lead to the establishment of a system as a method of managing governance in Indonesia after reform. The statement of Bird and Vaillancourt above is in line with the findings of research conducted (Limia 2014). Both of these studies show the large role of local governments (in Turkey and Poland) in efforts to overcome social problems faced by the community. These studies also confirm that local government can further improve the welfare of the community, compared to when the government was still in a centralized system. Also, studies conducted (Nak-ai 2018). also, show that the role played by local governments by collaborating with several stakeholders can improve people's lives(Sharma 2015). 
However, the problem is that after a long time Indonesia has implemented a decentralized system, the results have not been in line with expectations. Based on several studies (Hasjimzun 2014) shows that decentralization in various regions in Indonesia has not been able to achieve community welfare as the main objective of its implementation with a variety of factors that cause it. This condition must certainly be a concern because after all the decentralization policy is a national consensus as a solution to the problems of society during the era of centralization. Therefore, it is necessary to find the location of the problems faced concerning the achievement of the objectives of regional autonomy in Indonesia that have not yet been achieved.

This is in line with Law Number 32 of 2004 about Regional Autonomy, which states that regional governments in implementing regional autonomy must meet the needs of their regions by a predetermined budget to improve the welfare of their people. In carrying out autonomy, regions have obligations including improving the quality and life of the community, developing democratic life, realizing justice and equity, increasing basic education services, providing health care facilities, and providing adequate social and public facilities. Thus, theoretically, as mentioned earlier that the decentralized policy model should be able to bring a better level of welfare compared to a centralized system.

The fifth research journal "Creative Media as an Indonesian Youth Political Attitude" about creative media as a political attitude of Indonesian youth, in this journal describes political communication in which political communication consists of the discipline of communication combined with political science where the media has been designed to be used for discuss the world of Indonesian politics. Through this creative media the presidential candidates and legislative candidates will promote themselves, like communication in general this communication is used to attract young people to open their horizons and how to determine the right attitude in determining the direction of Indonesia going forward. In the journal also includes the theory of attitudes and political attitudes in this part of the theory the author includes the character G. Alport who explains about the attitude and someone to act. And one of Jalaludin Rahmat's figures who explained about the five definitions of attitude.

The next journal entitled The Behavior of Choosing Muslim Communities in the 2014 legislative elections conducted in the cotton district right in 
Bojonegoro Regency. Based on the data that has been found reveals that the programs that have been closed by legislative members participating in elections are an attraction for the public in making choices. The suitability of the program in the village can make the appeal to get the voice of the people. Therefore, the suitability of the program in the next five years is needed to capture the aspirations of the community so that the community will be more interested if the program is more pro-community. The other findings are about money politics carried out by several candidates and it is certain that candidates who distribute the money will get full votes from the public. If other candidates use money politics, the people will make their choices through the nominal amount of money that has been given. In this study using the theory of Anthony Downs's theory relating to rational voter behavior. As it is revealed that rational voters are selfish only concerned with their own interests or welfare, but not all humans put their own interests first, he only said that rational voters take more action to gain greater profits. On the other hand, mass organizations in the field do not favor one party or candidate, this is contrary to the theory of attitude function put forward by Angus Campbell who states that the attitude has been formed for a long time, since childhood, since childhood the community has been close to the culture of Nahdlatul Cleric. However, this does not affect the community because not all people who join the Nahdlatul Ulama mass organizations will choose parties or candidates whose backgrounds are the same as those of Nahdlatul Ulama (Handaningrum 2014).

Whereas in the analysis section the author discusses the participation of youth in Indonesian politics by looking at the present conditions of Indonesian youth currently experiencing stangnan can be said as the degradation of youth in Indonesia. In the sense that young people prefer to be apathetic about politics in Indonesia, this attitude is the beginning of the emergence of youth who are blind to politics in Indonesia, which of course has an impact on the quality of politics carried out 5 years through election activities. even young people consider that politics is now dirty conditions will get worse when the youth know how the process of democracy in Indonesia. Therefore, it is through the creative media of the winning team that it is expected that young people will change their mindset, which initially said that politics is bad or dirty to be good by watching with 
supporters of one another exhibiting their uploaded creativity through social media. from the conclusion we can know that youth political participation is a reflection of the political world in the future where young people will be even more qualified and expected to be a breath of fresh air in the world of Indonesian politics (Christany 2018).

The difference between this research and previous research that has been done is on the forms of roles that can be carried out by the Merangin District Government in the era of globalization and how they affect the welfare of society. the position of researchers to see the impact of the policies that have been given by the government to the level of community welfare.

\section{METHODS}

This study is a qualitative research that is understood as an approach that allows researchers to be able to do detailed descriptions and interpretations to get a holistic understanding (Marvasti 2004). The type of research is library research by reviewing data related to the Merangin Regency Government development policies and community welfare in the last 3 years (2016-2018).

Data collection is carried out through field survey activities through institutional data tracking in the form of data collection and or recording from agencies related to the development policy of Merangin Regency natural resource data (rubber and palm oil) and community welfare data(Badan Pusat Statistik 2018).

To analyze the data that has been obtained and collected, then qualitative data analysis techniques are used which are done in three ways, namely: data reduction, data presentation (displaying data), and concluding (Miles and Huberman 1992). Data reduction is the process of selecting, focusing on simplifying, abstracting, and transforming "rough" data that arise from written records in the field. Furthermore, the presentation of data is a collection of information arranged that gives the possibility of drawing conclusions and taking action. The final method used is drawing conclusions or verification, namely interpretation or interpretation of the entire data collected so that adequate conclusions can be obtained. 


\section{RESULT AND DISCUSSION}

The state role discourse in the era of globalization. In general, globalization is understood as a process of spreading global habits, the expansion of relationships across continents, the organization of social life on a global scale, and the growth of a shared global consciousness (Ritzer 2006). According to Giddens, globalization is the intensification of world relations that connect distant localities in such a way that some social events are formed by events that occur for miles and vice versa. Meanwhile, according to globalization is essentially a systematic effort to reduce all barriers of protection (protective barriers) to the flow of goods and capital, by and for the benefit of giant companies based on international trade rules. Based on the above understanding, globalization can be interpreted simply as a compression of space and time which becomes a necessity and periodization of the development of an era where there is an intensification of the process of community integration in various countries into a world community (Jati 2013).

Based on the opinion of Giddens the discourse of globalization gave rise to two major groups, each of which gave birth to a theory, namely the Radical Group on the one hand and the Skeptical Group on the other. In general, radical groups are identified as a group of social thinkers who support globalization because they regard it as a necessity in human life, while skeptics are known as intellectual groups who doubt its possibilities, even oppose its existence. To support his opinion, each of these groups put forward a variety of assumptions and data they have (Giddens 2002).

The debate that took place between the Radical and Skeptical Groups regarding globalization occurred around how the state or government should play a role. The Radical Group considers that the state or government does not need to take an important position in the era of globalization, on the contrary, the Skeptic Group instead states it must play a more important role. Historically, as a party that constitutionally plays an important role in a country, the government is not always a single player in the management of the country. Historical records reveal the dynamic role played by the government in developing the country. There are times when the government has a role, even very absolute, in carrying out 
development in a country, but there are also times when the government is no more than a compliment.

Historically, the role of the state in development can be divided into two parts, namely: the role of the 1950-1960 era state and the role of the 1970s state until now (winarno 2015). The role played by the state in the period before the 1970s was very significant in determining the direction and policy of the development of a nation, but after 1970 until now there was a cut in the role played by the state.

The debate over the role played by the state or government in this development according to Giddens (2002, p.7-8) gave rise to two major groups, each of which gave birth to a theory, namely the radical group on the one hand and the skeptical group on the other. In general, radical groups are identified as a group of social thinkers who support globalization because they regard it as a necessity in human life, while skeptics are known as intellectual groups who doubt its possibilities, even oppose its existence. To support his opinion, each of these groups put forward a variety of assumptions and data they have.

The role of the state in development began during the Second World War by controlling all national forces. According to Abidin (1986, p.20), the role of government is increasingly significant after the end of the war which has damaged various infrastructures to convince the people of development needs and invite them to participate, the process of nationalization of various economic institutions left behind by the invaders, coordination and complementarity between various industries and businesses, and carry out centralized planning development.

Keynes's theory becomes the basis for the need for government intervention in every aspect of development that is realized by the Marshall Plan Program so that it can lead America and Europe to triumph in the economic field and so on. This step was also followed by various Third World countries, such as Indonesia which implemented the Five-Year Development Plan (Repelita), Malaysia which implemented various policies to spur successive industrialization from 1970 to 1995 and India which formed the National Planning Commission to encourage the Plan Five Years (Winarno 2015).

According to Kamal Mathur (Pahrudin 2016), there are three ways by the state before 1970 in efforts to develop the nation, namely through government spending, through resource mobilization and participation in industrial production 
carried out in three policy areas (investment, trade, and finance). The first region is carried out by the state by issuing various policies to create a conducive investment climate to attract foreign investors to invest in the country. The same thing is also done by the state to policies on trade and financial aspects which have the core of creating a climate that enables the economy to develop properly.

In this regard, Michael Todaro (Pahrudin 2016), revealed the factors that underlie the necessary role of the state in development, namely: market failure, resource mobilization, and psychological impact. Market failures in stabilizing commodities and prices have an impact on the mislocation of resources which can be dangerous in the future. Resource mobilization is needed because developing countries generally face quality constraints of human resources so that the role of government makes the development direction more focused. With the strong and dominant role of the state, it will have a psychological impact on society so that development will be created that can achieve the expected goals.

The dominant role of the state in development after the Second World War began to receive criticism that began in 1970 along with the slowing down of the American and European economies after being victorious for almost 25 years. Efforts to reduce the role of the state were first carried out by Britain in the days of Prime Minister Margareth Thatcher and the United States under President Ronald Reagan (Winarno 2015). Thatcher reduced the role of the state in four public areas, namely: health services, education, unemployment benefits, and oldage pensioners. In contrast to the period before 1970 which had a paradigm of state-led development, cutting the role of the state after the victory of the Neoliberal Group in Europe and the United States shifted the perspective of policy to market-led development.

Criticism of the development paradigm that has been applied and the reduction in the role of the state in development has been carried out by those with a radical perspective. This is because globalization according to this group is understood as a new history that occurs in human life that places the traditional state into irrelevant, especially in the context of existing business units in a global economy. For radicals, national boundaries are no longer the time to be a topic of discussion because globalization has destroyed it (Winarno 2015). Also, the dominant role of the state in economic affairs as practiced before 1970 is claimed 
to be constraints and constraints that hamper the efficient use of scarce world resources (Pahrudin 2017).

Proposing a reduction in the role of the state is carried out so that the goals of globalization are achieved successfully. Related to this, Kenichi Ohmae (Hasjizum) proposed four reasons that reinforce his view of the marginalization of the role of the state which he called the " $\mathrm{i}$ " Factor. Investment is the first " $\mathrm{i}$ " factor, because the distribution of funds can spread to places that are outside the area of origin of the fund. The second "i" factor is industry, because its expansion does not recognize national borders anymore, but is based on market share considerations so that many companies operate far outside their original area. Information technology becomes the third " $\mathrm{i}$ " factor, due to the rapid development of these two entities so that they can cross national borders, even in just seconds. The last "i" factor that strengthens Ohmae's view of the marginalization of the role of the state is that globally oriented individual consumers can already access various needs throughout the world due to advances in information technology, without being impeded by national borders.

The discourse of the role of the state in development in the era of globalization has not yet ended with the shifting of policies to market-led development supported by several groups. According to trimming the role of the state in globalization forgets history because of the rapid development of globalization which is used as an excuse for its support groups to be undeniably the role of the state(Wolf 2016). Countries that are the main actors of globalization (North America, Western Europe, and East Asia) can now benefit greatly through corporations and international institutions as an implication of the role of the state through the various policies it produces. Also, said that corporations and international institutions that are the main agents of globalization certainly need a regional arena to play their role which is certainly politically represented by the state.

Still in the same context, Kavaljit Singh (Pahrudin 2016). also said that the role of the state is getting stronger and is very worthy to be put forward in the era of globalization. To strengthen his opinion, this radical figure put forward several justification reasons related to the strengthening role of the state in massive globalization activities around the world. The first reason, not all countries decrease or weaken their role in the era of globalization, because the level is very 
different from one country to another, depending on the size, military strength, and strength of the country. As a major world power and a major actor of globalization, the role of the United States is certainly not weak compared to some Third World countries in Asia and Africa because the level of size, military strength, and strength of the country are very different.

The second reinforcing factor is that the financial costs that must be incurred by the government to be part of globalization do not significantly undermine state finances. This is because a country that is increasingly integrated with other countries, the state expenditure will tend to increase rather than decrease. The third factor, the privatization of the public sector which is a prerequisite for globalization required by one of its actors (IMF) does not mean rejection of state intervention. This is because, although privatization, on the one hand, can cause a decrease in public ownership, on the other hand, this policy will have an impact on increasing state regulation through the formation of authority, competition regulation policies, openness norms, and other new policy measures. The last factor, although the role of the state will be reduced in economic aspects, but in other sectors, the role of the state will increase significantly, such as the increasing repressive attitude of the state towards its people who protest against government programs that are considered to benefit foreign corporations.

Strengthening the views above, Winarno (2005, p.148) proposed two reasons underlying the very significant role of the state in this globalization era(Winarno 2015). First, as the implications of colonialism in the past and globalization in the present, many people in the Third World are still wallowing with helplessness and poverty. This condition certainly requires the role of the state to carry out development that can improve their standard of living so that they can be aligned with other countries. Second, the system of globalization through market mechanisms must not be allowed to continue to dominate every aspect of people's lives because this method does not guarantee justice in the distribution of people's income. For each people to get their right to live better, it is necessary for the role of the state to overcome it through development that supports the fulfillment of people's aspirations.

Winarno (2005) also revealed the fact that several countries had been hit by the crisis and were able to overcome it due to the effective role of their 
government, as happened in South Korea and Malaysia. Through the actions of the government with an effective set of bureaucracy, South Korea and Malaysia managed to overcome the monetary and economic crisis that hit them and were able to rise from adversity. On the contrary, due to the absence of an effective role from the country as demonstrated by South Korea and Malaysia, Indonesia has not been able to overcome the monetary and economic crisis that wraps it up and its effects can still be felt today.

The policy of The Merangin Regency Government in the globalization era.Merangin Regency is one of the regencies in Jambi Province and is geographically bordered by Bungo Regency in the north, Sarolangun Regency in the east, Lebong Regency in the south and Kerinci Regency in the west. Overall the area of Merangin Regency is 7,679 km2 which consists of 24 sub-Regency and 372,205 inhabitants (Badan Pusat Statistik 2018).

As the largest area in Jambi Province, Merangin Regency has various natural resource potentials that are following the regional development orientation. Merangin Regency has 4 leading commodities that are the backbone of the population's economy in one of the Regency's in the west of Jambi Province, namely rubber, palm oil, coffee, and coconut. Based on BPS data (2018), Merangin Regency has several potential natural resources in the form of rubber covering an area of 132,192 hectares, oil palm covering an area of 53,792 hectares, robusta coffee with an area of 10,860 hectares and coconut with an area of 1,658 hectares.

Based on the views of Skeptics with a series of arguments related to globalization, it can be concluded that the role of government in development must remain or must be strengthened. Related to the discourse of the significant role of the state in overcoming these public problems, public policy is something that should be put forward. Especially if it is associated with efforts to overcome the problems that exist in society and it is the responsibility of the state through the government to overcome them. Thomas R. Dye (1981, p.1) said that public policy is what is done or not done by the government to overcome the problems faced by its people (Dye 1990). Meanwhile, Herald Laswell and Abraham Kaplan (1970, p.71) define public policy as a program that is structured with a set of objectives, values, and certain practices. On the other hand, Steven A. Peterson (in Nugroho, 2017, p. 203) defines public policy simply by considering it as an 
action taken by the government to overcome various problems(Riant 2018). Policies are essentially decisions that directly regulate the management and distribution of natural, financial and human resources in the public interest (Suharto, 2010, p. 110-112). Riant Nugroho (2017, p. 204) defines public policy as any decision made by the state, as a strategy to realize the goals of the state. Riant Nugroho (2017, p. 216) further said that the best public policy is an initiation that can motivate the community to build their respective competition, not vice versa, to plunge society into a pattern of dependency (Suharto 2010).

As the party assigned to manage the area, the Merangin Regency Government must be able to use its local potential as a basis for regional development. This is in line with the concept of development based on local potential which rests on the understanding that real development comes from within (local government and society) by relying on its potential (Karamoy 2015). Regions that have certain potential (natural resources and human resources) can apply development models that are appropriate to their characteristics. The hope is that by relying on resources from within the region, everyone feels ownership and development goals in the form of welfare will be achieved well.

Related to this, based on BPS Merangin 2018 data, 101,866 people are working in the agricultural sector (mainly rubber, palm oil, coconut, and coffee) with 36,905 households (HHS). Therefore, by focusing on the development of these three main commodities, the Merangin Regency Government has helped the lives of most of its residents. In this way, the level of welfare of the Merangin Regency community will also increase because the main source has been well managed by the local government as the main controller at the regional level. After the local potential to be managed so that regional development and welfare assumptions to be achieved is known, then what is the real form of policy that will be carried out by the Merangin Regency Government to realize it. In line with who interpreted the public policy as any decision made by the state or region to realize its objectives, the Merangin Regency Government made policies so that this local potential could be more useful for community development (Riant 2018). The efforts made by the Merangin Regency Government are based on the Concept of Deglobalization conducted by Walden Bello (2004) and carried out by an innovative bureaucratic system as proposed by Dernhart (2003). 
Based on The Bello's Deglobalization (2004) which is based on local needs, the Merangin Regency Government is oriented towards managing regional potentials to meet domestic needs. As it is known that domestic demand for rubber, palm oil, coconut, and coffee commodities is very large and is increasing every year. Rubber in Merangin Regency produces 61,360 tons/year, while demand for palm oil raw materials requires 54.6 million tons, but can only be met as much as 52.8 million tons. Meanwhile, coconuts need 20-21 billion eggs and only 12 billion can only be met, while coffee needs are 1.1 kilograms $(\mathrm{kg})$ per capita per year. This effort is certainly not easy, therefore an innovative regional instrument based on the concept of the New Public Service is needed by Dernhart.

The effort to build a region based on local potential in Merangin Regency is getting stronger with the vision and mission carried out by the widest area in Jambi Province. As a form of accommodation towards the desire to develop the region for the better, the Merangin Regency Government set the vision of 'Improving Development Towards Merangin EMAS' which means' building people's economy, clean and trustworthy towards Merangin, an advanced economy. safe, fair and prosperous'. In an effort to realize this big vision, the Merangin Regency Government strengthened its mission as outlined in the following 5 strategic steps: Improving the quality of bureaucratic services to the community by promoting transparency, efficiency, effectiveness and accountability; improve the quality of basic service infrastructure; Improving the quality of human resources through education and health; Increasing the economic development of small communities based on agribusiness and agriculture; and Improving the achievements of the younger generation and gender welfare.

The derivative activities of implementing the strategic steps summarized in the above mission have been carried out. Among these activities are improving road infrastructure in various areas of Merangin Regency, improving education and health facilities as well as infrastructure and increasing capacity for village officials through the Village Financial System Training (Siskeudes). Also, several policies are directly related to development based on local potential, which have been carried out by the Merangin Regency Government, namely: first, the formation of a Regionally Owned Enterprises (BUMD) Preparation Team for PT. Merangin Bima Tama through the Merangin Regent Decree Number 20/Pereko and SDA/2018. Second, the Gema Watanabe Program or Community Movement 
and Citizens Planting Residents. A program carried out to mobilize the community to use the yard and garden around the house to grow their daily needs of chili and vegetables. This program is intended so that the people of the Merangin Regency do not always have to buy basic needs that can be fulfilled independently. Third, the Geber Mewah Program or the Joint Movement to Return the Land of the Former Gold Mining into Rice Fields. The program is intended to encourage community members to utilize land that was previously used for illegal mining (PETI) or illegal mining into productive agricultural land. Fourth, the Lubuk Larangan Program is aimed at utilizing river resources that are widely distributed in Merangin Regency. The deepest parts of the river are marked as not allowed to carry out any activities there, so that river resources (especially fish) can be maintained and reproduce there. At certain times, such as approaching Eid, Lubuk Larangan is open to the public and every member of the community can take their fish for free by not damaging the river ecosystem.

The policies implemented in Merangin Regency are certainly intended to improve the welfare of the community. Related to this, although Merangin Regency does not have an oil and gas mine as a source of regional income (PAD), the data on community welfare is quite encouraging. Based on BPS data (2018), the rate of economic growth in the Merangin Regency has increased significantly in the last two years. In 2017, the economic growth of the Merangin Regency was $5.4 \%$, rising to $5.17 \%$ in 2018 or above the average of Jambi Province (4.71\%) and equal to the national level. Also, the Gini Index which is a calculation of the average income inequality in the Merangin Regency has been stable in the last two years (0.30). This figure shows that there is a stable distribution of community income in the Merangin Regency and is above Jambi Province (0.33) and nationally (0.38). Also, the Merangin Regency Human Development Index (HDI) as one of the welfare indicators is quite happy. During the last three years, the HDI of Merangin Regency experienced a significant increase, in 2016 (67.86), 2017 (68.30) and 2018 (68.81). Although this data is still below Jambi Province (70.65) and national (71.39), the rising trend of HDI in the Merangin Regency shows that development programs implemented by local governments in this region have a significant impact on society. Especially if the Merangin Regency Government continues to promote innovative policies based on local potential and 
synergize with stakeholders and be supported by active community participation. The same thing also applies to poverty rates that are still high $(9.43 \%)$, through the optimal implementation of the above policies, it is expected that the people of Merangin Regency will experience an increase in the standard of living in the future.

\section{CONCLUSION}

Globalization has become an unavoidable phenomenon and the practice has two sides, positive and negative. The government, especially the regional government after regional autonomy, plays a significant role through innovative and solutive public policies to take advantage of available opportunities and prevent the negative impacts of globalization. The Merangin Regency Government has issued a series of innovative policies based on local potential aimed at the welfare of the community. These policies have a significant impact on the lives of the people of the Merangin Regency, which are demonstrated through various promising welfare indicators.

\section{REFERENCES}

Agutino, Leo. 2016. Dasar-Dasar Kebijakan Publik.

Amien, A. Mappadjantji. 2005. Kemandirian Lokal: Konsepsi Pembangunan, Organisasi Dan Pendidikan Dari Perspektif Sains Baru 14(3).

Badan Pusat Statistik Kabupaten Merangin. 2018. "Kabupaten Merangin Dalam Angka 2018. Bangko.” BPS.

Bird, R., dan Vaillancourt, F. 1998. Fiscal Decentralization in Developing Countries.

Christiany Juditha \& Josep J. Darmawan. 2018. Penggunaan Media Digital Dan Partisipasi Politik Generasi Milenial: Jurnal Penelitian Komunikasi dan Opini Publik22 (2).

Dye, Thomas R. 1990. Understanding Public Policy.

Giddens, Anthony. 2002. Runaway World: How Globalization Is Reshasping Our Lives.

Handaningrum, Rohana. 2014. Persepsi terhadap kualitas calon legislative (caleg): Persona, Jurnal Psikologi Indonesia3(3). 
Hasjimzun, Yusnani. 2014. "Model Demokrasi Dalam Peningkatan Kualitas Pelayanan (Studi Otonomi Daerah Dalam Peningkatan Kesejahteraan Masyarakat Pasca Reformasi." Jurnal Dinamika Hukum 14(3).

Jati, Wasisto Raharjo. 2013. "Memahami Globalisasi Sebagai Evolusi Kapitalisme.” Jurnal Global Dan Strategi 7(2):243.

Jurdi, Syarifuddin. 2014. Dinamika Politik Kaum Muda Indonesia :Dialektika Politik Nasional dan Lokal6(2).

Karamoy, Arlyn A. 2015. Partisipasi Politik Generasi Muda Dalam Pembangunan Di Desa Sawangan Kecamatan Airmadidi Kabupaten Minahasa Utara1(7).

Kusmanto, Heri. 2014. "Jurnal Ilmu Pemerintahan Dan Sosial Politik UMA Partisipasi Masyarakat Dalam Demokasi Politik." Jurnal Ilmu Pemerintahan Dan Sosial Politik 2(1):77-89.

Limilia, Putri \& Evie Ariadne. 2018. Pengetahuan Dan Persepsi Politik Pada Remaja: Jurnal Psikologi Sosia 16(01): 45-55

Marvasti, Amir B. 2004. Qualitative Research in Sociology.

Miles, Matthew B. and Huberman, A. Michael. 1992. Analisis Data Kualitatif.

Nak-ai, Worayuth etc. 2018. "Community Public Policy Process for Solving Cadmium Contamination Problems in The Environment: A Case Study of Mae Sod Regency, Tak Province.” Journal of Social Sciences 59-66.

Nugroho riant. 2018. Dinamika Kebijakan Publik, Analisis Kebijakan Publik, Dan Manajemen Politik Kebijakan Publik.

Pahrudin, Hm. 2016. "Penetrasi Kapital Dan Dampaknya Terhadap Petani Karet Tabir Ilir Jambi Prespektif Teori Skeptis Globalisasi.Jurnal Ilmu Sosial Dan Ilmu Politik 22(2).

Pahrudin, Hm. 2017. "The Study of Government's Role for Welfaring Rubber Farmer in the Globalization Vortex." Jurnal Ilmu Sosial Dan Ilmu Politik 21(2):117-30.

Ritzer, George. 2006. The Globalization of Nothing: Mengkonsumsi Kehampaan Di Era Globalisasi.

Sharma, Chanchal Kumar. 2015. "Reimagining Federalism in India: Exploring the Frontiers of Collaborative Federal Architecture." Asia Pacific Social Science Review 15(1):1-25.

Sobari, Wawan. 2016. Anut Grubyuk in the Voting Process: The Neglected Explanation of Javannes Voters. Southeast Asian Studies 5 (2):239-268. 
Suharto, Edi. 2010. Membangun Masyarakat Memberdayakan Rakyat.

Tamanna, Meheri. 2015. "The Political Perception of Youth: Where Are We Heading To?" IOSR Journal Of Humanities And Social Science 20(7):65-70.

Winarno, budi. 2015. Globalisasi Wujud Imperialisme Baru: Peran Negara Dalam Pembangunan.

Wolf, martin. 2016. "Will The Nation-State Survive Globalization." Foreignaffairs.

Yustiningrum, RR Emilia. 2015. "Political Participation and Voting Behavior in General Election 2014.” Jurnal Penelitian Politik 12(1):117-35. 